\title{
Keputusan Pembelian E-Commerce Shopee Pada Generasi Milenial Di Kecamatan Johar Baru
}

\begin{tabular}{|c|c|}
\hline INFO ARTIKEL & Abstract \\
\hline 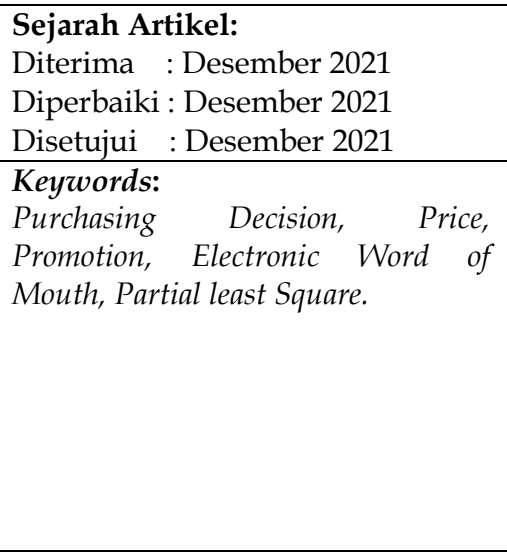 & \multirow[t]{2}{*}{$\begin{array}{l}\text { This research is a quantitative study that aims to determine the effect of price, } \\
\text { promotion, and EWOM on purchasing decisions at Shopee's e-commerce. This } \\
\text { study uses the millennial generation of Shopee users in Johar Baru District as } \\
\text { a sample. Samples taken were } 75 \text { respondents with the side probability method. } \\
\text { Data collection was carried out by distributing questionnaires. The data } \\
\text { analysis technique used is descriptive analysis and inferential analysis with } \\
\text { the analytical tool used is PLS (Partial Least Square) with a significant level of } \\
5 \% \text {. The results showed that Price has a correlation value of 0.786, Promotion } \\
\text { correlation value of 0.156, and EWOM correlation value -0.104. From the } \\
\text { analysis of the coefficient of determination, it can be explained that Price, } \\
\text { Promotion, and EWOM affect Purchasing Decisions in Shopee e-commerce } \\
\text { for the Millennial Generation in Johar Baru District by } 68.5 \% \text {, while the } \\
\text { remaining } 31.5 \% \text { is influenced by other variables outside of this study. } \\
\text { Abstraks }\end{array}$} \\
\hline & \\
\hline $\begin{array}{l}\text { Kata Kunci: } \\
\text { Keputusan Pembelian, Harga, } \\
\text { Promosi, Pemasaran dari mulut } \\
\text { ke mulut. } \\
\text { DOI: }\end{array}$ & $\begin{array}{l}\text { Penelitian ini merupakan penelitian kuantitatif yang bertujuan untuk } \\
\text { mengetahui pengaruh harga, promosi, dan EWOM terhadap } \\
\text { keputusan pembelian di ecommerce Shopee. Penelitian ini } \\
\text { menggunakan generasi milenial pengguna Shopee di Kecamatan Johar } \\
\text { Baru sebagai sampel. Sampel yang diambil sebanyak } 75 \text { responden } \\
\text { dengan metode probability samping. Pengumpulan data dilakukan } \\
\text { dengan penyebaran kuesioner. Teknik analisis data yang digunakan } \\
\text { adalah analisis deskriptif dan analisis inferensial dengan alat analisis } \\
\text { yang digunakan adalah PLS (Partial Least Square) dengan signifikansi } \\
5 \% \text {. Hasil penelitian menunjukkan bahwa Harga memiliki nilai } \\
\text { korelasi sebesar 0,786, nilai korelasi Promosi 0,156, dan nilai korelasi } \\
\text { EWOM -0,104. Dari analisis koefisien determinasi dapat dijelaskan } \\
\text { bahwa Harga, Promosi, dan EWOM memengaruhi Keputusan } \\
\text { Pembelian di e-commerce Shopee pada Generasi Milenial di } \\
\text { Kecamatan Johar Baru sebesar } 68,5 \% \text {, sedangkan sisanya } 31,5 \% \\
\text { dipengaruhi oleh variable lain di luar penelitian ini. }\end{array}$ \\
\hline $\begin{array}{l}\text { Korespondensi: } \\
\text { Nama: Alia Engka Nadita Putri } \\
\text { Email: aliaenka20@gmail.com }\end{array}$ & $\begin{array}{l}\text { ISSN: 2355-9543 (Print) } \\
\text { ISSN: 2460-3775 (Online) }\end{array}$ \\
\hline
\end{tabular}

\section{PENDAHULUAN}

Kini dunia telah menjadi satu karena kehadiran teknologi internet yang menjadi faktor terbesar dalam terjadinya perubahan pola pembelian masyarakat. Konsumen kini dapat membeli produk dimana pun dan kapan pun selama terhubung dengan internet. Di zaman konsumerisme saat ini, konsumsi masyarakat tidak 


\section{Keputusan Pembelian E-Commerce Shopee Pada Generasi Milenial Di Kecamatan Johar Baru}

Alia Engka Nadita Putri, Tati Handayani

terbatas, beriringan dengan perputaran dunia. Dengan memanfaatkan internet, kini dapat melakukan kegiatan pemasaran produk ataupun jasa dengan sebutan e-marketing (Winarso, 2020), terlebih disaat masa pandemi seperti ini yang mengharuskan masyarakat untuk mengurangi aktivitas keluar rumah. Sehingga kegiatan pemasaran dapat dilakukan di rumah dengan cara

memanfaatkan e-marketing saja (Awali, 2020).

Menurut laporan yang dipublish oleh

Kominfo.go.id pada tahun 2018, sejak tahun 2013 netter di Indonesia terus mengalami peningkatan tiap tahunnya. Hal tersebut dibuktikan oleh hasil riset perusahaan riset pasar yang berasal dari Inggris bernama e-Marketer dengan judul “Top 25 Countries, Ranked by Internet by Users 2013-2018" yang hasilnya menunjukan bahwa pengguna internet Indonesia menempati posisi terbanyak ke6 di dunia. E-Marketer memperkirakan Indonesia akan menggeser posisi Jepang di tahun selanjutnya (S. Susilowati \& Handayani, 2019), dikarenakan Indonesia terus mengalami peningkatan. Hal tersebut dapat dilihat pada gambar berikut ini:
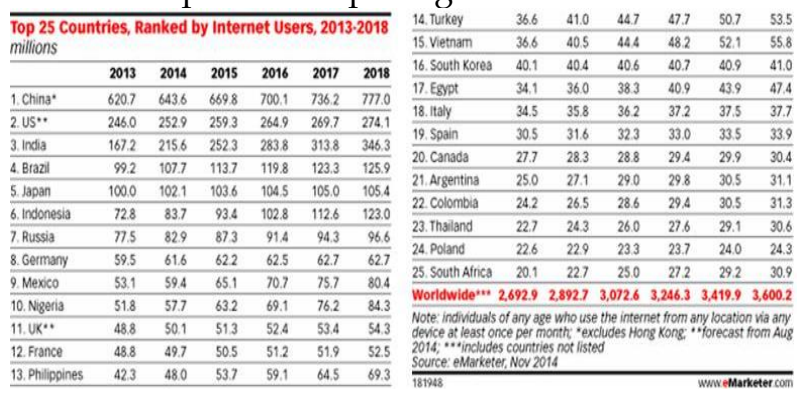

Gambar 1. Peringkat 25 Negara Teratas Pengguna Internet Tahun 2013-2018

Sumber: Kominfo.go.id (2018)

Pada gambar tersebut, dapat dilihat bahwa Indonesia mengalami peningkatan terus menerus selama 5 tahun hingga menembus angka 123M pengguna pada tahun 2018.

Hal itu dapat disimpulkan bahwa teknologi tidak pernah lepas dari kehidupan sehari-hari masyarakat dan akan terus mengalami perkembangan, kini masyarakat hidup berdampingan dengan perkembangan teknologi, hingga kini teknologi berada di dalam genggaman. Teknologi mengalami perkembangan sangat pesat di masa generasi milenial, hal itu berpengaruh terhadap perubahan pola kehidupan generasi milenial yang cenderung lebih unggul dalam memafaatkan perkembangan teknologi saat ini dibandingkan generasi sebelumnya (Rahmadan Dkk, 2020). Generasi milenial menjadikan teknologi sebagai bagian dari kehidupannya, tidak hanya untuk sekedar mencari kebutuhan, berbagi informasi atau bekerja, tetapi hampir semua hal yang dilakukan generasi milenial selalu menggunakan teknologi (Pohan \& Nur, 2019). Kompas.com memberitakan bahwa hasil dari riset yang dilakukan oleh Kredivo dan Katadata Insight Center (KIC) yaitu generasi milenial berkontribusi besar dalam transaksi e-commerce, yakni sebesar $85 \%$.

Popularitas e-commerce yang sangat tinggi saat ini, memicu munculnya berbagai toko online di Indonesia yang menyebabkan persaingan antar e-commerce semakin ketat. "Peta E-commerce Indonesia mengurutkan pemain besar e-commerce berdasarkan rata-rata pengunjung website . Berikut adalah data yang dikumpulkan selama tahun 2019 mulai dari quartal 1 sampai quartal 4 tahun 2019"(Safitri, 2020).

Tabel 1. Persaingan E-Commerce di Indonesia

\begin{tabular}{|l|c|c|c|c|}
\hline $\begin{array}{l}\text { Toko } \\
\text { Online }\end{array}$ & $\begin{array}{l}\text { Visitor } \\
\text { Quartal 1 }\end{array}$ & $\begin{array}{l}\text { Visitor } \\
\text { Quartal 2 }\end{array}$ & $\begin{array}{l}\text { Visitor } \\
\text { Quartal 3 }\end{array}$ & $\begin{array}{l}\text { Visitor } \\
\text { Quartal 4 }\end{array}$ \\
\hline Tokopedia & $137,200,900$ & $140,414,500$ & $65,953,400$ & $67,900,000$ \\
& $(1)$ & $(1)$ & $(1)$ & $(2)$ \\
\hline Shopee & $74,995,300$ & $90,705,300$ & $55,964,700$ & $72,973,300$ \\
& $(2)$ & $(2)$ & $(2)$ & $(1)$ \\
\hline Bukalapak & $115,256,600$ & $89,765,800$ & $42,874,100$ & $39,263,300$ \\
& $(3)$ & $(3)$ & $(3)$ & $(3)$ \\
\hline Lazada & $52,004,500$ & $49,620,200$ & $27,995,900$ & $28,383,300$ \\
& $(4)$ & $(4)$ & $(4)$ & $(4)$ \\
\hline Blibli & $32,597,200$ & $38,453,000$ & $21,395,600$ & $26,863,300$ \\
& $(5)$ & $(5)$ & $(5)$ & $(5)$ \\
\hline JD.ID & $10,656,900$ & $7,102,300$ & $5,524,000$ & $13,539,300$ \\
& $(6)$ & $(6)$ & $(6)$ & $(6)$ \\
\hline
\end{tabular}

Sumber: Iprice (2020)

Berdasarkan data pada tabel 1, jelas terjadi penurunan jumlah pengunjung dari awal tahun hingga akhir tahun, namun Tokopedia menempati posisi pertama jumlah pengunjung terbanyak hingga kuartal 3, yaitu sebesar 65,953,400 pengunjung, dengan perbedaan $17,8 \%$ lebih banyak dibanding Shopee yang hanya memiliki pengunjung sebesar 55,964,700, namun pada kuartal 4 Shopee mengalami pelonjakan kenaikan jumlah pengunjung sebesar 30,4\% yang berarti mengegeser posisi Tokopedia dan menjadi ECommerce yang terbanyak dikunjungi pada kuartal 4 yaitu sebanyak 72,973,300. Namun walaupun Shopee berada di posisi pertama saat akhir tahun, tapi dapat dilihat bahwa jumlah pengunjung Shopee mengalami kondisi fluktuatif selama tahun 2019.

"Shopee adalah pusat perdagangan elektronik yang berkantor pusat di Singapura di bawah SEA Group (sebelumnya dikenal dengan Garena). Shopee didirikan 2009 oleh Forrest Li. Shopee pertama kali diluncurkan di Singapura pada tahun 
2015, dan sejak itu memperluas jangkauannya ke Malaysia, Tahiland, Taiwan, Indonesia, Vietnam, dan Filipina. Mulai tahun 2019, Shopee juga sudak aktif di negara Brasil dan menjadikannya Shopee pertama di Amerika Selatan dan luar Asia. Shopee sendiri dipimpin oleh Chris Feng. Chris Feng adalah salah satu mantan pegiat Rocket Internet yang pernah mengepalai Zalora dan Lazada." (Wasli, 2020).

Akibat dari menjamurnya E-Commerce di Indonesia menimbulkan persaingan yang sangat ketat bagi para pelaku bisnis untuk menarik calon konsumen. Sebelum melakukan pembelian akan ada faktor-faktor yang mendukung untuk pengambilan keputusan membeli, salah satunya adalah harga, karena harga merupakan suatu yang krusial dan dapat mempengaruhi posisi suatu perusahaan (Lubis, 2015). Selain itu, menurut penelitian yang dilakukan oleh (Ansori \& Ansori, 2020), ketepatan dalam menetukan harga akan mempengaruhi ketertarikan calon konsumen untuk memilih produk tersebut.

Selain harga, promosi juga merupakan faktor yang dapat menunjang ketertarikan calon pembeli, menurut penelitian terdahulu yang dilakukan oleh (Susanti \& Gunawan, 2019), promosi merupakan salah satu bentuk komunikasi terhadap calon pembeli yang apabila pesan dari komunikasi tersebut tersampaikan dengan baik ke konsumen akan berpengaruh pada keingintahuan konsumen

\section{TINJAUAN PUSTAKA \\ Pemasaran}

Menurut (Hery, 2019, hlm. 3) mendefinisikan bahwa pemasaran merupakan upaya dalam mengidentifikasi kebutuhan dan kemauan orangorang dengan cara yang menguntungkan.

Menurut (Indrasari, 2019, hlm. 2) mendefinisikan bahwa pemasaran ialah suatu kegiatan yang terstruktur yang dilakukan oleh sebuah organisasi atau institusi supaya dapat menyanggupi permintaan pasar, pemasaran juga merupakan proses perkenalan suatu produk kepada calon konsumen.

Kemudian, menurut (Firmansyah, 2019, hlm. 2) menyimpulkan pemasaran adalah kegiatan yang dilakukan untuk memenuhi kebutuhan manusia dengan cara yang menguntungkan.

Lalu, menurut (Rizal, 2020) berpendapat bahwa pemasaran merupakan suatu proses sosial serta manajerial yang dilakukan untuk memenuhi kebutuhan dan utuk mendapatkan timbal balik yang sesuai. terhadap produk tersebut. Serupa dengan penelitian terdahulu yang dilakukan oleh (Ernawati, 2019) menyatakan bahwa promosi adalah cara perusahaan untuk membujuk, menginfromasikan, dan mengingatkan konsumen secara langsung atau tidak langsung tentang produk yang dijual.

Selanjutnya terdapat E-WOM (Electronic Word of Mouth) yang merupakan faktor lain yang memperngaruhi keputusan pembelian. Menurut penelitian terdahulu yang dilakukan oleh (Sandi, 2017), menyatakan bahwa E-WOM akan berpengaruh positif terhadap perusahaan apabila selaras dengan opini dan komentar yang ditinggalkan. Kemudian, menurut penelian terdahulu yang dilakukan oleh (Sindunata, 2018), dibanding informasi mengenai produk yang didapat dari perusahaan, masyarakat cenderung lebih memilih untuk mempercayai E-WOM.

Berdasarkan pada uraian di atas, maka peneliti tertarik untuk melakukan penilitian di Kecamatan Johar Baru dikarenakan banyak dijumpai aktivitas dari kurir resmi/ layanan jasa kirim resmi dari berbagai ecommerce terlebih Shopee, penelitian ini berfokus pada pengaruh Harga, Promosi, dan EWOM terhadap keputusan pembelian di Shopee oleh Generasi Milenial di kecamatan Johar Baru. Maka dari itu, penelitian akan diberi judul "Keputusan Pembelian E-Commerce Shopee pada Generasi Milenial di Kecamatan Johar Baru.

\section{e-Commerce}

Menurut (Susilowati, 2019) menyatakan bahwa e-commerce merupakan arena yang berisikan aktivitas transaksi dan pertukaran informasi, hal itu terjadi dikarenakan terhubungnya jutaan computer ke dalam satu jaringan raksasa (internet).

Kemudian menurut (Pradana, 2016) ecommerce merupakan suatu kegiatan bisnis yang dilakukan secara online, yang melakukan aktivitas tersebut disebut pengecer online dan dilakukan penjualan secara langsung ke konsumen.

Lalu, (Palinggi \& Limbongan, 2020) menyatakan bahwa e-commerce merupakan suatu kegiatan bisnis yang dilakukan dengan memanfaatkan teknologi digital atau yang biasa disebut internet.

Pendapat lain dari (Anjani \& Santoso, 2018) mendefinisikan bahwa e-commerce adalah penyebaran, pembelian penjualan, pemasaran produk melalui jaringan computer yang melibatkan pertukaran data secara elektronik, transfer dana, system inventori otomatis dan pengumpulan data secara otomatis. 


\section{Keputusan Pembelian}

Menurut (Setiadi, 2015, hlm. 10) mengemukakan bahwa keputusan pembelian berisikan banyak faktor seperti budaya, social, pribadi, dan psikologi dari calon konsumen, namun terdapat banyak faktor lain yang diluar dari kendali pemasar itu sendiri, namun dapat diperhitungkan.

Menurut (Jamarnis \& Susanti, 2019) mendefinisikan bahwa keputusan pembelian adalah suatu serangkaian pemikiran yang dilakukan oleh konsumen pada saat sebelum membeli / hingga setelah membelinya.

Kemudian, menurut (Rondonuwu dkk, 2020) menyatakan bahwa keputusan pembelian merupakan kegiatan perorang atau individu yang melakukan pengambilan keputusan secara langsung untuk melakukan pembelian produk yang ditawarkan.

(Rossanty Dkk, 2018, hlm. 14) menyatakan bahwa keputusan pembelian merupakan rangkaian yang memiliki 2 dimensi yaitu degree (peran serta konsumen terhadap keputusan pembelian) dan decision (banyaknya informasi yang didapat konsumen untuk menentukan keputusan pembelian).

Harga

Menurut (Indrasari, 2019) mendefinisikan harga merupakan nilai yang dinyatakan dalam satuan uang, dan merupakan jumlah yang dibayar oleh pembeli. Karena harga juga merupakan nilai dari suatu barang atau jasa tersebut.

Pendapat lain terdapat dari (Sasongko Dkk, 2020) harga merupakan salah satu unsur dari bauran pemasaran yang dinyatakan dalam sejumlah uang guna mendapat kepemilikan dari suatu produk.

Sedangkan menurut (Manampiring \& Wenas, 2016) menyatakan bahwa harga merupakan salah satu kunci dari kegiatan pemasaran yang mempengaruhi faktor-faktor produksi yang ada. Harga juga merupakan alat dalam perekonomian, sehingga apabila barang yang dijual memiliki nilai yang tingi maka akan sebanding juga dengan harga yang ditetapkan (Nadila \& Usman, 2020).

Harga menjadi salah satu faktor yang dapat menarik konsumen pada segmen kecil dari pasar yang besar, hal itu menjadikan penetapan harga adalah sesuatu yang sangat kompleks dan harus dilakukan dengan strategi yang kritis (Kotler dan Armstrong, 2011).

Promosi
Menurut (Sari, 2019) promosi ialah salah satu kegiatan perusahaan untuk mengenalkan produk yang dijualnya kepada konsumen.

Kemudian, pendapat lain dari (Thabit \& Raewf, 2018) menyatakan bahwa promosi merupakan salah satu penentu keberhasilan dalam suatu kegiatan pemasaran.

Lalu (Handini dkk, 2019, hlm. 138) menyatakan bahwa promosi ialah hal yang penting dan relatif terhadap elemen pemasaran lainnya. Promosi kini dikenal dengan istilah komunikasi dalam pemasaran, karena disadari perlunya hubungan antar elemen bauran promosi.

Menurut Tjiptono (2015) kegiatan promosi yang dilakukan oleh perusahaan didasari oleh sebuah keinginan untuk mencapai suatu keuntungan atau laba.

e-WOM

Menurut (Oktaviani, Astuti, \& Firdiansjah, 2019)mendefinisikan eWOM eWOM merupakan kumpulan pernyataan positif dan negative yang dibuat oleh calon pelanggan, aktual atau pelanggan yang telah melakukan pembelian tentang produk atau perusahaan yang tersedia untuk masyarakat melalui internet.

Menurut (Ismagilova dkk, 2017, hlm. 14) menyatakan bahwa eWOM merupakan komunikasi informal yang ditujukan untuk pembeli terkait dengan penggunaan atau karakteristik produk yang dijual.

Menurut (Oktaviani dkk, 2019) mendefinisikan bahwa eWOM merupakan komentar tentang produk yang telah diposting di internet yang dapat digunakan sebagai perhitungan dalam memutuskan melakukan pembelian.

\section{Model Penelitian Empirik}

Dalam penelitian ini terdapat tiga variabel bebas dan satu variabel terikat. Variabel independent pada penelitian ini yaitu Harga, Promosi, dan Electronic Word of Mouth sedangkan variabel dependentnya adalah Keputusan Pembelian. Digambarkan sebagai berikut:

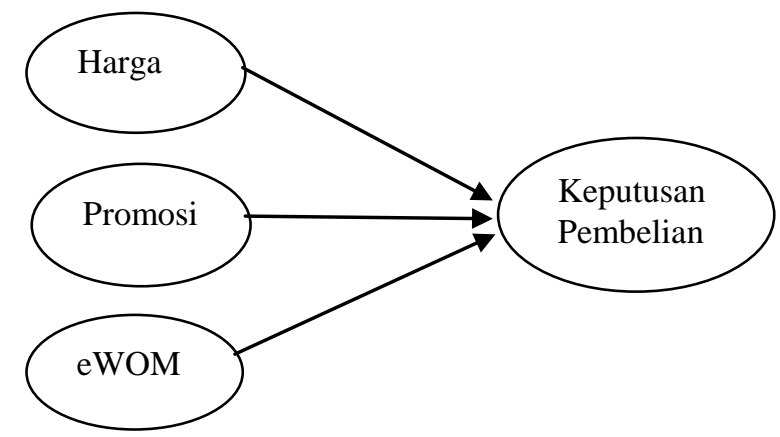


Gambar 1: Model Penelitian Empirik

Suber: Data Diolah Peneliti (2021)

Hipotesis

Berikut hipotesis yg diambil untuk penelitian ini:

H1: Diduga harga mempunyai pengaruh yang positif terhadap keputusan pembelian pada toko online Shopee.

H2 : Diduga promosi mempunyai pengaruh yang positif terhadap keputusan pembelian pada toko online Shopee.

H3 : Diduga e-WOM mempunyai pengaruh yang positif terhadap keputusan pembelian pada toko online Shopee.

\section{METODE PENELITIAN \\ Pendekatan Penelitian}

Teknik pengumpulan data yang akan di lakukan adalah dengan menggunakan data kuantitatif. Data kuantitatif adalah data yang disajikan dengan angka atau numerik yaitu dapat berupa ordinal, interval atau rasio. Data numerik yang digunakan dari hasil penelitian ini menggunakan skala ordinal yaitu menggunakan skala Likert.

\section{Teknik Analisis Data}

Menggunakan uji t teknik analisis penelitian ini menggunakan metode analisis Partial Least Square. Perolehan perhitungan indeks berdasarkan rumus diatas kemudian diinterpretasikan dengan metode tiga kotak (three box method) oleh (Ferdinand, 2006) di dalam buku karangan (Riyanto \& Hatmawan, 2020).

\section{Sampel Penelitian}

Sampel yg digunakan dalam penelitian ini adalah konsumen generasi milenial yang pernah melakukan pembelian di toko online Shopee di wilayah Kecamatan Johar Baru.

\section{HASIL PENELITIAN}

Gambaran Umum Responden

Tabel 2. Gambaran Umum Responden

\begin{tabular}{ccc}
\hline Wilayah & Frekuensi & Persentase \\
\hline Johar Baru & 29 & $38.7 \%$ \\
\hline Galur & 18 & $24 \%$ \\
\hline Tanah Tinggi & 15 & $20 \%$ \\
\hline $\begin{array}{c}\text { Kampung } \\
\text { Rawa }\end{array}$ & 13 & $17.3 \%$ \\
\hline Jenis Kelamin & Frekuensi & Persentase \\
\hline Laki - laki & 38 & $50.7 \%$ \\
\hline Perempuan & 37 & $49.3 \%$ \\
\hline Usia & Frekuensi & Persentase \\
\hline $24-29$ tahun & 60 & $80 \%$ \\
\hline
\end{tabular}

\begin{tabular}{ccc}
\hline $30-34$ tahun & 7 & $9.3 \%$ \\
\hline $35-39$ tahun & 8 & $10.7 \%$ \\
\hline Pekerjaan & Frekuensi & Persentase \\
\hline Karyawan & 22 & $29.3 \%$ \\
\hline $\begin{array}{c}\text { Pelajar/ } \\
\text { Mahasiswa }\end{array}$ & 27 & $36 \%$ \\
\hline $\begin{array}{c}\text { Ibu Rumah } \\
\text { Tangga }\end{array}$ & 10 & $13.3 \%$ \\
\hline $\begin{array}{c}\text { Pegawai } \\
\text { Swasta }\end{array}$ & 5 & $6.7 \%$ \\
\hline $\begin{array}{c}\text { Wirausaha } \\
\text { Pegawai } \\
\text { Negeri }\end{array}$ & 1 & $1.3 \%$ \\
\hline $\begin{array}{c}\text { Pendapatan } \\
\text { <Rp. 500.000 }\end{array}$ & Frekuensi & Persentase \\
\hline $\begin{array}{c}\text { Rp. } 500.000- \\
1.000 .000\end{array}$ & 11 & $26.6 \%$ \\
\hline $\begin{array}{c}\text { Rp. } 1.000 .000- \\
2.000 .000\end{array}$ & 6 & $14.7 \%$ \\
\hline >Rp.3.000.000 & 38 & $8 \%$ \\
\hline S & & $50.6 \%$ \\
\hline
\end{tabular}

Sumber: Data Diolah Peneliti (2021)

\section{Analisis Inferensial}

Pendekatan statistika yang pengolahannya dengan menggunakan prosedur hipotesis sehingga dapat membuat keputusan tentang suatu populasi (Mufarrikoh, 2017, hlm.4). Pada penelitian ini alat yang digunakan untuk analisis inferensial adalah PLS (Partial Least Square) dengan software smartPLS versi 3.2.6. Berikut merupakan hasil diagram jalur yang sudah di calculate menggunakan smartPLS 3:

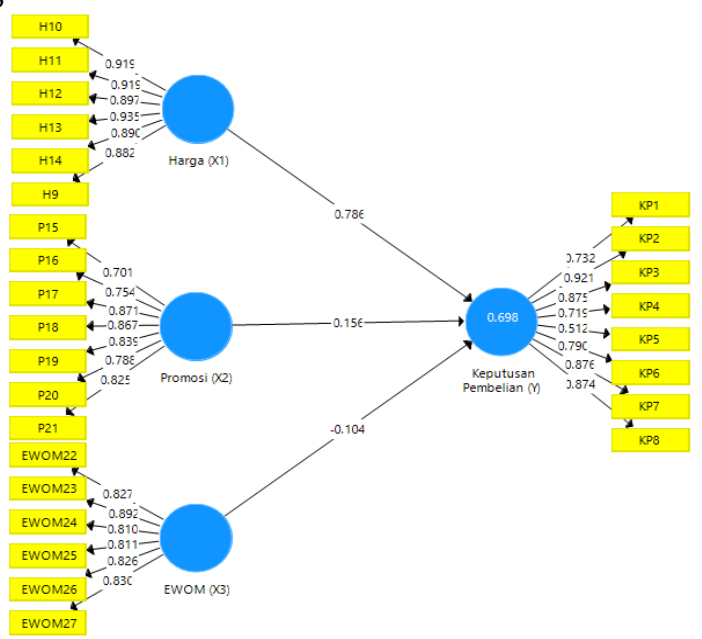

Gambar 3: Hasil output PLS 3.0

Sumber: Data Diolah Peneliti (2021)

\section{Uji Validitas}

\section{Uji Validitas Konvergen}

Uji validitas konvergen dihitung dengan cara melihat hasil dari outer loadings yang apabila 
Keputusan Pembelian E-Commerce Shopee Pada Generasi Milenial Di Kecamatan Johar Baru Alia Engka Nadita Putri, Tati Handayani

bernilai lebih dari 0,5 maka dinyatakan valid dan dapat mewakili setiap variabelnya serta memenuhi persyaratan uji validitas konvergen (convergent validity).

Tabel 3. Nilai Outer Loadings

\begin{tabular}{|c|c|c|c|c|}
\hline Indikator & $\begin{array}{c}\text { Keputusan } \\
\text { Pembelian } \\
(\mathrm{Y})\end{array}$ & $\begin{array}{l}\text { Harga } \\
(\mathrm{X} 1)\end{array}$ & $\begin{array}{l}\text { Promosi } \\
\text { (X2) }\end{array}$ & $\begin{array}{c}\text { EWOM } \\
(\mathrm{X} 3)\end{array}$ \\
\hline KP1 & 0,732 & & & \\
\hline KP2 & 0,921 & & & \\
\hline KP3 & 0,875 & & & \\
\hline KP4 & 0,719 & & & \\
\hline KP5 & 0,512 & & & \\
\hline KP6 & 0,790 & & & \\
\hline KP7 & 0,876 & & & \\
\hline KP8 & 0,874 & & & \\
\hline H9 & & 0,882 & & \\
\hline $\mathrm{H} 10$ & & 0,919 & & \\
\hline H11 & & 0,919 & & \\
\hline $\mathrm{H} 12$ & & 0,897 & & \\
\hline H13 & & 0,935 & & \\
\hline H14 & & 0,890 & & \\
\hline P15 & & & 0,701 & \\
\hline P16 & & & 0,754 & \\
\hline $\mathrm{P} 17$ & & & 0,871 & \\
\hline P18 & & & 0,867 & \\
\hline P19 & & & 0,839 & \\
\hline $\mathrm{P} 20$ & & & 0,788 & \\
\hline P21 & & & 0,825 & \\
\hline EWOM22 & & & & 0,827 \\
\hline EWOM23 & & & & 0,892 \\
\hline EWOM24 & & & & 0,810 \\
\hline EWOM25 & & & & 0,811 \\
\hline EWOM26 & & & & 0,826 \\
\hline EWOM27 & & & & 0,830 \\
\hline
\end{tabular}

\begin{tabular}{ccccc}
\hline $\begin{array}{l}\text { Keputusan } \\
\text { Pembelian }\end{array}$ & 0,671 & 0,832 & $\mathbf{0 , 7 9 7}$ & \\
\hline Promosi & 0,847 & 0,849 & 0,734 & $\mathbf{0 , 8 0 9}$
\end{tabular}

Sumber: SmartPLS 3.0 (data diolah)

Tabel 5.Average Variance Extracted (AVE)

\begin{tabular}{l|l|l|l|r}
\hline & & & Average & Variance \\
& & & Extracted (AVE) & \\
\hline Keputusan Pembelian & 0,636 & \\
\hline Harga & & & 0,823 & \\
\hline Promosi & & 0,654 & \\
\hline EWOM & & 0,695 & \\
\hline
\end{tabular}

Sumber: SmartPLS 3.0 (data diolah)

\section{Uji Reliabilitas}

Pengujian ini memiliki syarat nilai harus lebih dari 0,7 yang telah dipastikan memenuhi kriteria.

Tabel 6.Composite Reliability (CR)

Sumber: Hasil Output SmartPLS 3.2.6

\section{Uji Validitas Diskriminan}

Dilakukannya uji validitas diskriminan untuk mengukur keakuratan variabel penelitian dengan syarat nilai harus diatas 0,5 maka dinyatakan validmelalui table Fornell-Lacker Criterium dan Average Variance Extracted ( $A V E$ ) dapat dilihat dari hasil output nilai SmartPLS 3 sebagai berikut:

Tabel 4.Fornell-Lacker Criterium

\begin{tabular}{cccc}
\hline & EWOM & Harga & $\begin{array}{l}\text { Keputusan } \\
\text { pembelian }\end{array}$ \\
\hline EWOM & $\mathbf{0 , 8 3 3}$ & & \\
\hline Harga & 0,819 & $\mathbf{0 , 9 0 7}$ & \\
& & &
\end{tabular}

\begin{tabular}{l|l|l|}
\hline & & \multicolumn{2}{|c|}{ Composite Reliability } \\
\hline Keputusan Pembelian & 0.932 & \\
\hline Harga & 0.965 & \\
\hline Promosi & 0.929 & \\
\hline EWOM & 0.932 & \\
\hline Sumber: SmartPLS 3.0 (data diolah)
\end{tabular}

Selain itu juga dilakukan pengujian realibiltas dengan syarat yang sama menggunakan hasil dari Cronbach Alpha sebagai berikut:

- Tabel 7. Cronbach Alpha

\begin{tabular}{l|l|l|l|l}
\hline & & & Croancbach Alpha \\
\hline Keputusan Pembelian & 0.913 & \\
\hline Harga & & 0.957 & \\
\hline Promosi & & 0.910 & \\
\hline EWOM & & 0.912 & \\
\hline
\end{tabular}

Sumber: SmartPLS 3.0 (data diolah)

Uji Koefisien Determinasi (R2)

Pengujian ini dilakukan untuk mengetahui berapa besar kontribusi keputusan pembelian, harga, promosi, dan EWOM yang sisanya dipengaruh oleh variable bebas lainnya yang tidak diikutsertakan dalam penelitian ini.

Tabel 8.R-Square Adjusted

\begin{tabular}{l|l}
\hline & R Square \\
\hline
\end{tabular} (Y)

Sumber: Hasil Output SmartPLS 3.2.6

Uji Hipotesis

Tabel 9. Hasil Uji Hipotesis 


\begin{tabular}{ll|l|l|l}
\hline & & $\begin{array}{l}\text { Original } \\
\text { Sample }\end{array}$ & $\begin{array}{l}\text { T } \\
\text { Statistics }\end{array}$ & $\begin{array}{l}\text { Values } \\
\text { Varga }\end{array}$ \\
\hline $\begin{array}{l}\text { Keputusan } \\
\text { Pembelian }\end{array}$ & $\rightarrow$ & 0,786 & 5,369 & 0,000 \\
\hline $\begin{array}{l}\text { Promosi } \\
\text { Keputusan } \\
\text { Pembelian }\end{array}$ & $\rightarrow$ & 0,156 & 1,071 & 0,285 \\
\hline $\begin{array}{l}\text { EWOM } \\
\text { Keputusan } \\
\text { Pembelian }\end{array}$ & $\rightarrow$ & $-0,104$ & 0,396 & 0,692 \\
\hline
\end{tabular}

Lalu untuk variabel electronic word of mouth (EWOM) menunjukkan koefisien pengaruh negatif antara EWOM terhadap keputusan pembelian sebesar -0.104 yang artinya juga tidak berpengaruh signifikan terhadap keputusan pembelian. Berdasarkan uraian-uraian di atas, hasil penelitian ini juga bertolak belakang dengan penelitian terdahulu yang dilakukan oleh (Soinbala \& Bessie, 2019) dan (Kristiawan \& Keni, 2020) dengan hasil penelitian yang menyatakan bahwa EWOM yang diberikan oleh suatu e-commerce mempunyai

Sumber: Hasil output smartPLS 3.2.6

Diketahui ttabel yang digunakan pada penelitian ini adalah 1,994 yang diperoleh dari rumus $\mathrm{df}=\mathrm{N}-\mathrm{k}$ atau $\mathrm{df}=75-4=71$, dengan derajat kepercayaan atau tingkat kebenaran sebesar $95 \%$ atau alpha sebesar 0,05 .

\section{PEMBAHASAN}

Berdasarkan hasil penelitian ini, data menunjukkan bahwa variabel harga berpengaruh signifikan terhadap keputusan pembelian pada generasi milenial di Kecamatan Johar Baru. Hal tersebut ditunjukkan dari hubungan positif yang terjadi pada variabel harga terhadap keputusan pembelian,hasil penelitian ini sejalan dengan beberapa penelitian terdahulu yang dilakukan oleh (Sudaryanto et al., 2019) dan (Widyastuti, 2018) yang menyatakan bahwa variabel harga memiliki pengaruh terhadap keputusan pembelian konsumen, dengan hasil penelitian yang menyatakan dengan adanya pemberian harga yang kompetitif yakni lebih murah dan terjangkau dapat mendorong dan mempengaruhi konsumen dalam memutuskan suatu pembelian melalui platform ecommerce.

Selanjutnya, terlihat dari perolehan nilai original sample yang menghasilkan angka positif 0.786, sedangkan promosi berpengaruh positif sebesar 0.156 yang artinya tidak berpengaruh signifikan terhadap keputusan pembelian.Berdasarkan uraian di atas, maka hasil penelitian ini tidak sejalan dengan penelitian yang dilakukan oleh (Napik, Qomariah, \& Santoso, 2018) yang menyatakan bahwa promosi yang diberikan oleh suatu e-commerce memiliki pengaruh terhadap keputusan pembelian konsumen. Namun penelitian ini berbanding lurus dengan penelitian yang dilakukan oleh (Oktapiani, 2020) dengan hasil penelitiannya yang mengungkapkan bahwa promosi yang ditawarkan oleh suatu e-commerce mampu mempengaruhi seseorang untuk melakukan pembelian, namun tidak berpengaruh secara signifikan pengaruh positif dan signifikan terhadap keputusan pembelian konsumen. Shopee sebagai ecommerce ritel global telah menyediakan akses untuk memudahkan pembeli dan penjual saling berhubungan dengan mudah mengenai transaksi atau suatu produk yang dijual, hal itu menjadikan ulasan dari berbagai customer yang telah membeli suatu produk dari Shopee atau bahkan selebritas pun tidak mempengaruhi para generasi milenial di Kecamatan Johar Baru dalam pengambilan keputusan pembelian mereka.

\section{SIMPULAN DAN SARAN}

Hasil penelitian membuktikn bahwa harga berpengaruh positif dan signifikan dengan keputusan pembelian, sedangkan promosi berpengaruh positif terjadap keputusn pembelian namun tidak signifikan, lalu Electronic Word of Mouth berpengaruh negative dan juga tidak signifikan terhadap keputusan pembelian. Berdasarkan hasil dari analisis data yang telah didapat, peusahaan untuk lebih memperhatikan harga, promosi dan EWOM supaya dapat lebih memajukan perusahaan.

\section{DAFTAR PUSTAKA}

Abdullah, S., \& Sutanto, T. E. (2015). Statistika Tanpa Batas. Jakarta: Transmedia.

Anjani, M. R., \& Santoso, B. (2018). Urgensi Rekonstruksi Hukum E-Commerce Di Indonesia. Law Reform, 14(1), 89. https://doi.org/10.14710/lr.v14i1.20239

Ansori, P. B., \& Ansori, P. B. (2020). Pengaruh Harga, Lokasi Dan Kualitas Produk Terhadap Keputusan Pembelian Konsumen Cv. Zafira Teknik Pekanbaru. Eko Dan Bisnis: Riau Economic and Business Review, 11(1), 11-19. https://doi.org/10.36975/jeb.v11i1.253

Awali, H. (2020). Urgensi Pemanfaatan EMarketing Pada Keberlangsungan Umkm Di 
Keputusan Pembelian E-Commerce Shopee Pada Generasi Milenial Di Kecamatan Johar Baru Alia Engka Nadita Putri, Tati Handayani

Kota Pekalongan Di Tengah Dampak Covid19. BALANCA : Jurnal Ekonomi Dan Bisnis Islam, 2(1), 1-14.

https://doi.org/10.35905/balanca.v2i1.1342

Chaffey, D., \& Smith, P. (2017). Digital Marketing Excellence: Planning, Optimizing and Integrating Online Marketing, Edition 5 (5th ed.). New York: Routledge.

Chairina, R. (2019). Analisis Manajemen Sumber Daya Manusia (Sidoarjo). Zifatama Jawara.

Djimantoro, J., \& Gunawan, V. C. (2020). Pengaruh e-WOM, Kualitas Makanan dan Kualitas Pelayanan Terhadap Keputusan Pembelian di Rumah Makan Kakkk Ayam Geprek. Universitas Kristen Petra, X(X), 187-196.

Endra, F. (2017). Pedoman Metodologi Penelitian (Statistika Praktis). Malang: Zifatama Jiwara.

Ernawati, D. (2019). Pengaruh Kualitas Produk, Inovasi Produk Dan Promosi Terhadap Keputusan Pembelian Produk Hi Jack Sandals Bandung. JWM (Jurnal Wawasan Manajemen), 7(1), 17 . https://doi.org/10.20527/jwm.v7i1.173

Firdaus, T., \& Abdullah, T. (2017). E-WoM: Pengaruhnya terhadap Keputusan Pembelian Tamu Restoran di Bandung Utara. THE Journal : Tourism and Hospitality Essentials Journal, 7(1), 21.

https://doi.org/10.17509/thej.v7i1.6843

Firmansyah, A. (2019). Pemasaran: Dasar dan Konsep (1st ed.). Qiara Media.

Firmansyah, A. (2020). Pengantar E-Marketing (T. Q. Media, Ed.). Jawa Timur: CV. Penerbit Qiara Media.

Frida, C. V. O. (2020). Pengantar Bisnis. Yogyakarta: Garudhawaca.

Ghozali, I. (2013). Aplikasi Analisis Multivariate dengan Program IBM SPSS 21 (VII). Semarang: Badan Penerbit Universitas Dipenogoro.

Gulliando, D. (2020). The Effect of Product Quality, Price and Promotion on Purchasing Decisions. Innovation Research Journal, 1(1), 34. https://doi.org/10.30587/innovation.v1i1.11 90

Handini, S., Sukesi, S., \& Astuti, H. K. (2019). Pemberdayaan Masyarakat Desa Dalam
Pengembangan UMKM Di Wilayah Pesisir (N. Azizah, Ed.). Surabaya: Scorpio Media Pustaka.

Hermawan, A. (2020). Penelitian Bisnis - Paragidma Kuantitati. Jakarta: Grasindo.

Hery, H. (2019). Manajemen Pemasaran. Jakarta: Gramedia Widiasarana Indonesia.

Indrasari, M. (2019). Pemasaran dan Kepuasan Pelanggan (1st ed.). Surabaya.

Iprice.co.id. (2020). Peta E-Commerce Indonesia. Retrieved from Jakarta website: https://iprice.co.id/insights/mapofecommer ce/

Ismagilova, E., Dwivedi, Y. K., Slade, E., \& Williams, M. D. (2017). Electronic Word of Mouth (eWOM) in the Marketing Context: A State of the Art Analysis and Future Directions. Switzerland: Springger.

Jamarnis, S., \& Susanti, F. (2019). Pegaruh Harga Dan Periklanan Melalui Internet Terhadap Keputusan Pembelian Produk Sabun Merek Lux Pada Mahasiswa Stie "Kbp" Padang. https://doi.org/10.31227/osf.io/xz3d8

Jaminyasa, I. M., Pulawan, I. M., Martadiani, A. A. M., \& Amerta, I. M. S. (2017). The marketing mix affect on the consumer buying decision (case study of sausage products at PT. Aroma Denpasar). International Journal of Social Sciences and Humanities, 1(2), 65-74. https://doi.org/10.29332/ijssh.v1n2.44

Katrin, I. L., Setyorini, D., \& Masharyono, M. (2017). Pengaruh Promosi terhadap Keputusan Pembelian di Restoran Javana Bistro Bandung. 246-254.

Khanfar, I. A. (2016). The effect of promotion mix elements on Consumers Buying Decisions of Mobile Service : The case of Umniah Telecommunication Company at. European Journal of Business and Management, 8(5), 94100. Retrieved from www.iiste.org

Kominfo.go.id. (2018). Pengguna Internet Indonesia Nomor Enam Dunia. Retrieved from https://kominfo.go.id/content/detail/4286/ pengguna-internet-indonesia-nomor-enamdunia/0/sorotan_media

Kristiawan, T. A., \& Keni, K. (n.d.). Pengaruh packaging, social media marketing dan electronic 
Jurnal Studi Manajemen dan Bisnis

Vol. 8 (2) 2021: 35-43

word of mouth terhadap keputusan pembelian busana brand lokal 1). 15(2), 244-256.

Lubis, A. (2015). Pengaruh Harga dan Kualitas Produk Terhadap Keputusan Pembelian Surat Kabar Pada PT. Suara Barisan Hijau Harian Orbit Medan. Ilmiah Manajemen Dan Bisnis,
16(02), 1-11.

https://doi.org/10.30596/jimb.v16i2.949 